\author{
Tomasz Seweryniak ${ }^{1, A C D}$
}

Department of Sport Coaching, Chair of Communication and Management in Sport University School of Physical Education in Wroclaw

\author{
Agnieszka Nowak ${ }^{2, \text { A-D }}$ \\ Department of Didactics of Sport, Chair of Theory in Sports Training \\ University School of Physical Education in Wroclaw
}

\begin{abstract}
Aneta Stosik ${ }^{3, C D}$
Department of Sport Coaching, Chair of Communication and Management in Sport University School of Physical Education in Wroclaw
\end{abstract}

\title{
Selected elements of motivational impact on sport performance in professional volleyball teams
}

\begin{abstract}
The purpose of this study is to present techniques and means through which professional sport teams coaches may influence their players' motivation. It includes analysis of present solutions used in practice and indicates directions for potential improvements. The conclusions of this study are based on a series of dedicated survey concerning various elements of motivational impact. The research was carried out among polish coaches of professional men's volleyball league. The studies of literature combined with practical experience, allowed the authors to present a set of elements of motivational impact, including motivating methods referring to different sources and forms of motivation. The results show that in the process of motivation coaches resort to both individual and collective techniques of influence. Motivational means declared to be used by respondents include: motivational speech, ongoing assessment of actions, raising voice, using reward and punishment system, code of honor and motivational recordings with own and opponent's actions.
\end{abstract}

Keywords: motivation, sport coach, players, professional sport team

\footnotetext{
${ }^{1}$ dr Tomasz Seweryniak, e-mail: tomasz.seweryniak@awf.wroc.pl

${ }^{2}$ mgr Agnieszka Nowak, e-mail: agnieszka-anna-nowak@wp.pl

${ }^{3} \mathrm{dr}$ Aneta Stosik, e-mail: aneta.stosik@awf.wroc.pl
} 


\section{Introduction}

The meaning of appropriate course of the process of motivating athletes, so they can achieve results adequate to their potential, has been underlined for many years and is reflected in several scientific papers (Martens 2009, Czajkowski 2004, Franken and Brown 1995, Franken 2005, Vallerand and Standage 2008, Geczi et al., 2009, Murray 1996). Said process can improve or deteriorate the level of involvement and, in consequence, affect the efficiency of a team. According to Obuchowski (2000) actions are based on tasks, which are the state of affairs whose execution results from one's own intentions. It is particularly important to differentiate task from requirement. Therefore, efficiency means to keep optimal (in relation to individual potential) effectiveness of actions as a function of three factors: one's personality, the style of his or her actions, and social arrangement in which he or she performs. In sport, especially in team games, the system of these three impact forces may appear in several relations and embed different power of influence. It is the team coach who determines the manner of such influence in the most significant way. Therefore, to act efficiently, coaches not only need to know the players and their environment but also have to be able to assign appropriate tasks (Mesjasz 2014). Moreover, there are authors who consider utmost level of athletes' motivation to be more important than any other element leading to achievement of good results (Czajkowski 2004, Gillet et al., 2012, Karwiński 2005). Taking this into account, it can be expected that coaches working with professional players will pay a lot of attention to and undertake many actions in said area. The status of professional athletes fulfilling their duties based on provisions of a contract in some sense justifies a situation where they are treated similar to employees of businesses outside sport industry, which has been indicated in the following papers: Puciato (2013), Łasiński (2003), R. Panfil (2004), Seweryniak (2003) and K. Witkowski et al. (2011). Consequences of such approach can be noticed in the influence of a superior (in this case - a coach) on this particular kind of employee (an athlete). One of said consequences is widening the range of motivational impulses by adding variety of material factors, including financial ones. As a result of literature analysis (Cramer and Jackschath 1998, Griffin 2005, Listwan 2006, Panfil R. 2000, Stosik and Morawski 2009, Armstrong 2005, Gonzalez 2013, Maxwell 2013) we have elaborated several potential elements of motivational impact used by coaches in relation to individual players and the team as presented in Table 1. The table also includes numbers of questions as they have appeared in the survey in relevance to particular elements.

The aim of this paper is a description and analysis of motivational methods used by coaches of a top league (polish: ekstraklasa) of men's volleyball.

Research questions posed in the context of the set forth aim:

1. To what extent do the coaches use motivation taking players' individuality into account?

2. To what extent is individual and group motivation used?

3. To what extent is material and non-material motivation applied?

4. What techniques and tools do coaches apply in order to motivate their players? 
5. How do coaches differentiate motivational impact in relation to training period?

6. Do coaches have influence on the form of material motivation of players?

7. Do coaches monitor and differentiate the effectiveness of used motivation on players and, if so, in what manner do they do it?

\section{Material and method}

The research has been conducted using diagnostics poll method with questionnaire survey. This dedicated survey was based on the studies of literature combined with authors' practical experience. The questionnaire was provided in both paper and electronic form with an online access. The authors intended to survey Polish coaches who are currently working or worked in the past in professional men's volleyball league. Potential and, in consequence, actual number of surveyed individuals has therefore been significantly affected by its characteristics. The latter is one of the reasons for relatively low number of respondents. 11 coaches participated in this study in the period between October 2013 and March 2014. Said coaches have worked in professional league in different years since the beginning of its existence i.e. the year 2000 (http://www.plps.pl/Historia.html) . Then the results were subjected to qualitative and quantitative analysis.

The survey was elaborated based on the studies of literature and practical experience of players and coaches which enabled authors to provide elements of motivational impact presented in Table 1. The survey includes 47 questions. Some of them are closed questions with three possible answers ('yes', 'no', 'sometimes'). Five questions were mixed - after choosing positive answer ('yes', 'sometimes') the respondent was asked to expand their answer. Questions posed in the survey refer to various elements of motivational impact, which can be applied by coaches of professional sport teams. The questionnaire survey was then placed on an electronic platform in order to provide respondents with easier access to it. Apart from the electronic form, the survey could also be provided and filled in on paper.

Table 1. Elements of motivational impact of coaches

\begin{tabular}{|l|l|l|l|}
\hline Lp & $\begin{array}{l}\text { Elements of } \\
\text { impact }\end{array}$ & $\begin{array}{l}\text { Description } \\
\text { of } \\
\text { motivational } \\
\text { actions }\end{array}$ & $\begin{array}{l}\text { Questions } \\
\text { in survey }\end{array}$ \\
\hline 1 & $\begin{array}{l}\text { Individuation } \\
\text { players, personality, setting personal goals for } \\
\text { different motivational type, personality } \\
\text { features; differentiation of players based on } \\
\text { their optimum level of stimulation. }\end{array}$ & $1-10$ \\
\hline 2 & $\begin{array}{l}\text { Extent of } \\
\text { individual and } \\
\text { group } \\
\text { motivation }\end{array}$ & $\begin{array}{l}\text { Situations where coaches use individual or } \\
\text { group approach, setting group goals, involving } \\
\text { the team in planning tasks and goals, jointly } \\
\text { developing a training plan. }\end{array}$ & \\
\hline
\end{tabular}




\begin{tabular}{|c|c|c|c|}
\hline 3 & $\begin{array}{l}\text { Extent of } \\
\text { material and } \\
\text { non-material } \\
\text { motivation }\end{array}$ & $\begin{array}{l}\text { Distinction between the impact of material and } \\
\text { non-material motivation, situation where } \\
\text { coaches used material and non-material } \\
\text { motivation to bigger extend. }\end{array}$ & $18-20$ \\
\hline 4 & $\begin{array}{l}\text { Motivational } \\
\text { tools and } \\
\text { techniques } \\
\text { used by } \\
\text { coaches }\end{array}$ & $\begin{array}{l}\text { Pointing out players' mistakes, raising voice, } \\
\text { notifying well and badly performed elements } \\
\text { and those which needed corrections, using } \\
\text { motivational speeches , showing recordings } \\
\text { with well -performed actions of own team and } \\
\text { those badly performed by the opponents before } \\
\text { the game, working based on friendly } \\
\text { relationships with full confidence, knowing } \\
\text { private matters of players, using reward and } \\
\text { punishment system and a code of honor. . }\end{array}$ & $21-29$ \\
\hline 5 & $\begin{array}{l}\text { Differentiation } \\
\text { of action } \\
\text { depending on } \\
\text { training period }\end{array}$ & $\begin{array}{l}\text { Number of used verbal motivation Turing } \\
\text { tournaments and games, alterations to number } \\
\text { of verbal motivation in relation to training } \\
\text { period. }\end{array}$ & $30-35$ \\
\hline 6 & $\begin{array}{l}\text { Coach's } \\
\text { influence on } \\
\text { material } \\
\text { motivational } \\
\text { tools }\end{array}$ & $\begin{array}{l}\text { Coach's influence on used material motivation, } \\
\text { the form of players' contracts, bonuses and } \\
\text { financial rewards granted. Making bonuses } \\
\text { depending on results and team involvement. } \\
\text { Establishing bonus tables within the team and } \\
\text { the specifics of its granting (individual or } \\
\text { group) and the knowledge of players } \\
\text { themselves on the reasons bonuses are granted. }\end{array}$ & $36-43$ \\
\hline 7 & $\begin{array}{l}\text { Differentiation } \\
\text { of } \\
\text { motivational } \\
\text { actions Turing } \\
\text { trainings and } \\
\text { games and } \\
\text { monitoring of } \\
\text { effects. }\end{array}$ & $\begin{array}{l}\text { Monitoring motivational actions used, looking } \\
\text { for better solutions in case of inefficient } \\
\text { impact of current motivational system. } \\
\text { Discussing players' feelings and opinions on } \\
\text { motivational approach applied, presuming that } \\
\text { game result reflects effectiveness of } \\
\text { motivation. }\end{array}$ & $44-47$ \\
\hline
\end{tabular}

Source: Own work.

\section{Results}

Collected results were divided into groups relating to elements of motivational impact, having regard to particular questions and responds and developed in the form of a diagram (Figure 1). It should be noticed that in case of five questions $(5,14,23,27,31)$ only 10 respondents provided an answer (some of them left empty space in the questionnaire). 


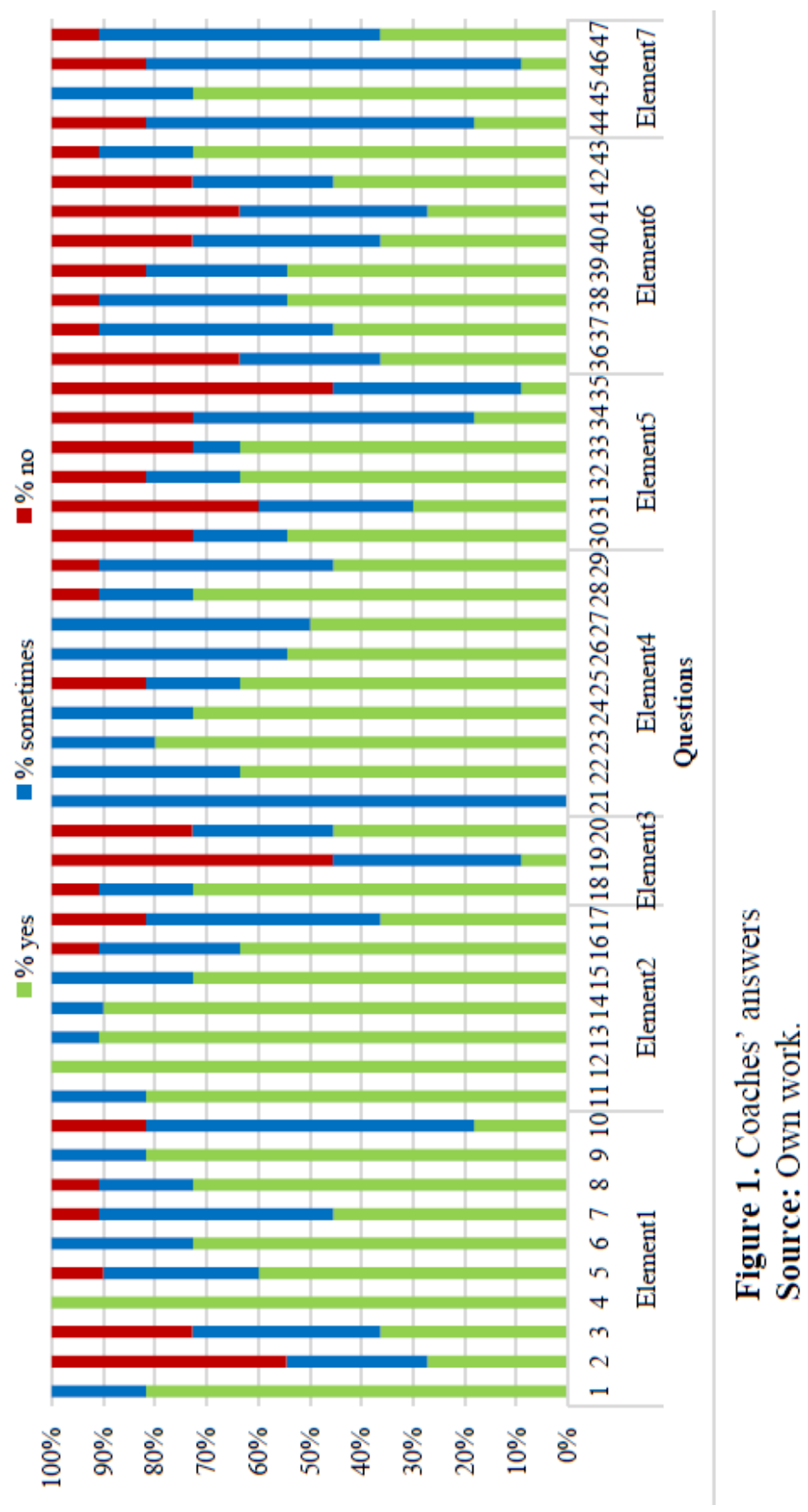


The study indicates that majority of coaches try to find out what kind of motivation characterizes certain players (Fig. 1; question 1; 81,8\% ,yes”, 18,2\% „no") and that a significant group (question 2; 45,5\% ,no" and question 3; 36,4\% „yes") makes an effort to differentiate impact. All respondents set personal goals for players (question 4, 100\%,yes") and a lot of them takes into account personality type (question 6; 72,7\% ,yes”). A fairly large group of coaches helps to maintain intrinsic motivation with external stimuli (question 5; 54,5\% 'yes'). Respondents answers indicate that the group of coaches avoiding criticism and presenting patience towards players oriented to fail is the same as the group of those acting contrary (question 7; 45,5\% 'yes' i 45,5\% 'no'), whereas a lot of them boost players' confidence regardless the situation (question $8 ; 72,7 \%$ 'yes'). According to the respondents they are eager to use motivational 'pep talk' addressed to individuals insufficiently stimulated (question 9; 81,8\% 'yes'), however, this also happens towards those optimally stimulated (question 10; 18,2\% 'yes' and 63,6\% 'often'). It seems that surveyed coaches are highly aware that motivation means 'psychological state contributing to the level of one's involvement' and that 'it includes factors that cause, define and maintain behaviors heading towards certain direction' (Stoner, Freeman, Gilbert as cited in Stosik, Leśniewska 2012)

Although it is common among coaches (question 11; $81,8 \%$ 'yes') to address players individually to motivate them, they chose to communicate with the team as whole more often (question 12; 100\% 'yes'). Motivation is also willingly executed through setting group goals (question 13; 90,9\% 'yes'), involving players into planning of tasks and goals (question 14; 81,8\% 'yes') and jointly developing plan of trainings and tasks (question 15; 72,7\% 'yes'). External rewards are presented as external indicators of achieving goals by significant number of respondents (question 16; 63,6\% 'yes'), whereas only a few of them defines success in motivating athletes under the category of realization of personal goals (question $17 ; 36,4 \%$ 'yes').

Vast majority of coaches noticed differences in the power of impact of material and non-material incentives (question 18; 72,7\% 'yes'), however, when analyzing answers concerning superiority of material or non-material incentives, significant differences between used practices can be observed (question 19, question 20). Statements referring to superiority of non-material incentives (question $20 ; 45,5 \%$ 'yes'), over practices where material ones dominate (question 19; 9,1\% 'yes') are worth noticing.

The results suggest that coaches use wide variety of methods and techniques in order to motivate their subordinates. The respondents declare that they sometimes point out players mistakes to achieve the latter (question 21; $100 \%$ 'often'). The answers are similar in case of talking with players failing to execute commends, raising voice and applying reward and punishment system (questions 23,24 and $2872,7 \%$ 'yes'). Motivational techniques used less commonly or occasionally include: notifying well-performed actions (question 22; 63,6\% 'yes', $36,6 \%$ often') and using video recordings with game actions (question 25; 63,6\% 'yes', 18,2\% 'no'; 18,2\% 'often'). Interestingly two of the respondents never used any video recordings. All coaches declare to avoid treating players as mere 
employees and state that they strive to get to know their subordinates as human beings (questions 26, 27; 0\% 'no'). Furthermore, similar group of coaches described such behaviors as consistent or occasional part of their work. The respondents willingly referred to the reward and punishment system (question 28; 72,7\% 'yes'). The tool in the form of Decalogue or code of honor was used in half of cases and the same number of respondents used it often (question 29; 45,5\% 'yes', 45,5\% 'often'). Data concerning extent of verbal motivation during matches and trainings are very ambiguous (questions 31 and 32) although, vague domination of such action during matches can be noticed. Far more significant tendency appears in relation to dependence of intensity of verbal motivation on training period (question 32;63,6\% 'yes') with the most intense in preparatory period (question 33; 63,6\% 'yes') and significantly less intense in starting and transient period (questions 34, 35).

The results of the study reflect strong differentiation of the impact coaches have on used forms of material motivation (question 36) because all answers received similar amount of indication. It could, therefore, be presumed that coaches' impact was significant if we take sum of positive answers - ('yes'-36\% and 'often'$27,3 \%$ ) into account, although it seems too far-reaching simplification. Close and ambiguous structure of answers that might prove certain trend can be noticed in questions (questions 37 and 38) concerning coaches impact on particular tools of material motivation (provisions of contracts and allocation of bonuses). Despite ambiguous responses, considering number of positive answers and these indicating partial influence, it can be stated that coaches have certain possibility to affect players' performance using said tools. According to gathered responses it is difficult to determine definitely, whether the bonuses are actually dependant on game results, (question 39), or on personal involvement, (question 40), however, dependency on results has been indicated more often (54.5\% 'yes' and $27.3 \%$ 'often'). It is similarly difficult to find a tendency which might prove that certain solutions related to team bonuses are preferable (question 41). Relatively large group of respondents uses tables based on which bonuses are calculated (question 42, 45.5\% 'yes', 27.3\% 'often'), although significant group does not resort to this tool at all (27.3\% 'no'). Answers indicating to relatively big extend that players are aware why they have been granted with bonuses (question 43; 72.7\% 'yes'), combined with answers to previous question, suggest other then said tables, ways of calculating bonuses.

Answers to questions referring to 7 . element are similar in terms of monitoring effects of undertaken motivational actions (question 44) and talks with players concerning results of used motivation (question 46). The most numerous group of coaches declared to resort to such solutions occasionally (72.7\% 'often'). The coaches definitely seek efficient motivational means if the effects of current action proves unsatisfactory (question $45 ; 72.7 \%$ 'yes'). It is immensely interesting what coaches stated on potential reflection of players motivation on game results (question 47). Only one respondent definitely denied such statement. 


\section{Discussion}

The aim of this study was to describe and analyze motivational methods used by coaches of top polish league of men's volleyball.

Naglak (2001) and Martens (2009) in their theories distinguished two groups of athletes: success-oriented and failure-oriented. Not only have they divided players into said groups but they also paid particular attention to a completely different approach to each of them. The authors described the essence of separate approach to both categories as the representatives of each tend to interpret their actions, successes and failures in a totally contrasting way.

The research showed that all coaches strived to recognize motivational types of players but some of them used equal amount of motivation for both groups and did not differentiate players based on motivational category. It might have been a consequence of using various incentives. Coaches who motivated all players in the same way might have paid closer attention to other aspects such as: personality type and their intrinsic motivation. Focusing on said elements they might have presumed that additional division into success-oriented and failure-oriented players would not be justified in that case.

Martens (2009) described how does a pep talk affect athlete's stimulation. He insisted that only those stimulated less then desired should be motivated. Although, in a discipline such as volley ball, higher level of stimulation is more beneficial, the players must not exceed it, as if they do their performance proves to be less efficient then in case of optimal level of stimulation (see also: Czajkowski 2014).

The results show that only two coaches did not use pep talk towards players who had already been optimally stimulated. Seven of them did so sometimes and two of them always. It might be a consequence of coaches approaching their teams as a group. The talk before the game is addressed to a whole team rather than individuals and maybe therefore the coaches who wanted to underline the unity of a team and to save some time, addressed their pep talks to entire teams of players. It is likely that individuals who were optimally stimulated learned to 'switch-off' during said meetings, so not to get 'put off stride' or over-motivated. It is also likely that the coaches were not aware of a fact that some bed performance was not caused by unnecessary talk which putting players 'off stride' but their daily incapacity. It seems regretful that surveyed coaches do not appreciate the power and value of persuasion as specific impact tool. Persuasion is a motivational mean that does not imply anything but through its component tools tries to change attitude and the way motivated person things. Through this group of means both motivating and motivated parties try to reach the same goal desired by both of them. Persuasion is based on mutual dialogue of motivating and motivated, consultation and commonly set goals (Stosik, Leśniewska 2012).There are two types of persuasion: a reasonable persuasion in a form of consultation, acceptance, negotiations, inspiration and coaching and an emotional persuasion appealing to the sphere of emotions. The latter appears in such forms as: convincing, solicitation or calling for. It is assumed that when comparing reasonable and emotional persuasion the first one proves to be less effective and to have less efficient motivational impact. 
Several researchers such as: Stosik and Morawski (2009), Panfil (2000) and Martens (2009) have underlined the meaning of setting team and personal goals. They state, that personal goals are related to team goals and that they identify with a team through acceptance and compatibility of personal and team goals. The main problem stems from measurement of personal value of a player through balance of wins and losses. As result one maintains self-confidence by deteriorating others self esteem. If the players see success as an achievement of personal goals that enables them to refrain from comparing themselves to others. When winning a game becomes less important than execution of personal goals, the players become far more motivated to train, which allows them to work on their personal achievement with the assistance of a coach. Then contest is no longer recognized as a final effect but rather as a periodical test in the process of executing personal goals. The players do not assess themselves as failing or succeeding depending on game result but by estimating what abilities or actions they have learned. Studies show that outstanding players concentrate mainly on their personal goals rather than on defeating others. When allowed to set their own goals - with the assistance of a coach who helps to keep them realistic- the players take responsibility for their personal progress. Having a sense of control they take credit for successes and responsibility for failure. This is the first step into efficient motivation of an athlete.

The survey confirm importance of setting personal and team goals. All coaches explicitly stated that they have set personal goals and made sure that they were adjusted to individual needs. Moreover, ten of them have also set group goals and only one of them did so from time to time. None of the respondents rejected setting group goals for their team. The coaches have been well aware of the significance of involving players into planning, goal setting and how deeply it affects motivation and achievement. They have also confirmed that personal goals set for players allow to use their full potential so that they feel fulfilled once they have accomplished their goals.

Listwan (2006) draws attention to the meaning of control of efficiency of used incentives. It is necessary to check on a regular basis, whether motivation chose by coaches actually affects their players. As every team consists of several completely different individuals, each of them will need different motivational factors. If you want to develop and help develop your players you need to monitor effectiveness of certain incentives on player in question and be ready to choose another incentive as the 'old one' may not be efficient anymore.

Some of the answers to survey questions relating to monitoring of efficiency of motivation may raise concerns. Only two respondents controlled effectiveness of motivation (seven of them did so sometimes) and only one of the coaches actually discussed with players the outcome of used motivation (eight respondents did so sometimes). Why is it so rare that the coaches seek follow up from their subordinates? Maybe because, based on their experience, they simply knew whether the players were actually motivated after receiving certain incentives. But it is also likely that the coaches lack tools allowing them to estimate efficiency of certain motivational actions. 


\section{Conclusions}

1. Individual approach to players (element 1) combined with influencing a team as a whole (element 2) should be presumed positive and can be recommended a good practice. The study, however, showed significant differences in coaches' actions that may be assessed as failure or, on the contrary, as adjusted to certain needs or circumstances.

2. Subjective treatment of a team in the process of motivation is a common practice among respondents and so are specific goals (personal and group). Nevertheless, it would certainly be valuable to use particularly defined success, referring to achieving individual mastery and personal commitment into team success, to bigger extent.

3. Analysis of a range and frequency in which material and non-material incentives are used indicated superiority of a non-material motivation, whereas material one refers to actions undertaken during tournaments to very little extent. Therefore, it is recommended as follows: objectively measured efficiency of sport actions and influence of players on the results of contests should be combined with financial incentives of different values.

4. Declared variety of used methods and techniques creates favorable conditions for efficient motivation, however, consistent motivational systems organizing coaches' actions and preventing from lack of coordination should clearly be build on these grounds.

5. The respondents differentiated motivational impact on players according to training period, which seems desirable. Declared high intensity of verbal persuasion in preparatory period then restricted in starting and further in transient period is difficult to assess unambiguously.

6. Limited influence of coaches on used forms of material motivation creates conditions hindering efficient motivation of athletes. It, therefore, seems to be desirable to unable coaches as direct superiors of professional players and main motivating party to become more influential in the process of creating material motivational systems.

7. Infrequent monitoring of efficiency of motivation seems to be a mistake. It might be resulting from lack of convenient and uncomplicated measuring tools and, therefore, it is highly recommended to spread existing and to develop new techniques providing follow-up information on the effectiveness of coaches motivating actions.

8. One of the most interesting conclusions is this showing that coaches quite clearly relate game results to the level of players' motivation, which indicates the necessity to further popularization and development of knowledge among sport coaches.

Summarizing, the efficiency of motivation is not only dependent on all kinds of incentives affecting particular players and the team as a whole, but also on verity of individuals included in the process. Diversification among personalities, tempers, internalized cultural patterns, systems of values, perceptions and many other areas show that no such thing as universal or unified motivational system 
exists. It is worth adding the concept of well known researchers - Robert Yerkes and John D. Dodson who tried to explain efficiency of fulfilled tasks through the level of motivation and stimulation. It appeared that a human being gets best results when his or her level of stimulation remains optimum. If the level of motivation to perform certain task is to high or to low the outcome will automatically be deteriorated. It is therefore an important suggestion for sport coaches (Sikorski 2004). Primary objective of motivation is to identify such means and actions that appeal to imagination and desires of individual players. Therefore, motivation is a process of interaction between two parties: motivating (coach) and motivated (player). In order to achieve efficiency of this mutual relation, the coach needs to know behavioral mechanisms, motivational methods and techniques as well as needs and expectations of his or her players. There is no other way to get efficient results, satisfying for whole team, then having a coach aware of needs, aspirations and motives of individual players. A policy of a sport coach is successful when the team achieves the optimum level of performance, while individual needs and expectations of each player are met, thus creating certain supportive and effective culture and team spirit. Incentives should motivate players to commit and contribute effort for future results which are determined through mutual agreement between a coach and his player. According to reinforcement theory, rewarding positive behavior increases probability that it will continue in future, which proves beneficial for the motivating party. Several factors originating from this group of tools are used to motivate both players and teams.

\section{References}

1. Armstrong, M., A Handbook of Human Resource Management Practice, 10th ed., Kogan and Page, London, Philadelphia, 2006.

2. Cramer, D., and Jackschath, B., Fußballpsychologie, 2nd ed., Meyer \& Meyer Verlag, Aachen, 1998.

3. Czajkowski, Z., Nauczanie techniki sportowej, Centralny Ośrodek Sportu, Warszawa, 2004.

4. Franken, R. E. and Brown, D. J., Why do people like competition? The motivation for winning, putting forth effort, improving one's performance, performing well, being instrumental, and expressing forceful/aggressive behavior, Personality and Individual Differences, 01/1995.

5. Franken, R. E., Human Motivation, 6th edn., Cengage Learning, 2006.

6. Géczi, G., Vincze, G., Koltai, M and Bognár, J., Hungary Elite Young Team Players' Coping, Motivation and Perceived Climate Measures, Physical Culture and Sport. Studies and Research, 2009, 46(1), 229-242.

7. Gillet, N., Berjot, S., Vallerand, R., Amoura, C. and Rosnet, E., Examining the motivation-performance relationship in competitive sport: A clusteranalytic approach. International Journal of Sport Psychology. 2012, 43, 79102.

8. Gonzalez, R., Becoming Unstoppable: How to Be an Olympian in Business and in Life, Aspen Publishing, 2008.

9. Griffin, R.W., Management, 11th ed., Cengage Learning, Mason, 2005. 
10. Historia, http://www.plps.pl/Historia.html. Access 03.11.2014.

11. Karwiński, M., Motywowanie sportowców do uzyskiwania wysokich wyników, https://www.akademiasiatkowki.com.pl/b/motywowaniesportowcow-do-uzyskiwania-wysokich-wynikow/0?r=163, 2005. Access 25.10.2014.

12. Listwan, T., ed., Zarządzanie kadrami. Warszawa: Wydawnictwo C.H. Beck, 2006.

13. Łasiński, G., Sprawność zarządzania organizacją sportową, Wydawnictwo Akademii Wychowania Fizycznego we Wrocławiu, Wrocław, 2003.

14. Martens, R.: Successful Coaching, 3 rd edn., Human Kinetics, Champaign, Illinois, 2004.

15. Maxwell, J.C., The 5 Levels of Leadership. Proven Steps to Maximize your Potential, Center Street, New York, 2011.

16. Mesjasz, J., Dylematy pomiaru efektywności zarządzania zasobami ludzkimi. in: Antczak, Z. and Borkowska, S., eds., Przyszłość zarządzania zasobami ludzkimi. Dylematy i wyzwania, Wydawnictwo Difin , Warszawa, s. 68-69, 2014.

17. Murray, E.J., Motywacja i uczucia, PWN, Warszawa, 1968.

18. Naglak, Z., Teoria zespołowej gry sportowej. Kształcenie gracza, Wydawnictwo Akademii Wychowania Fizycznego we Wrocławiu, Wrocław, 2001.

19. Obuchowski, K., Galaktyka potrzeb. Psychologia dążeń ludzkich, 2nd edn., Zysk i S-ka Wydawnictwo, Poznań, 2000.

20. Panfil, R., Edukacja uzdolnionego gracza i zarządzanie zespołem sportowym, Wydawnictwo Akademii Wychowania Fizycznego we Wrocławiu, Wrocław, 2000.

21. Panfil, R., Zarządzanie produktem klubu sportowego, Akademia Umiejętności Managment \& Coaching, Wrocław, 2004.

22. Puciato, D., Efektywność narzędzi motywacyjnych, Rozprawy Naukowe AWF we Wrocławiu, 2013, 40(1), 110-117.

23. Seweryniak, T., Proces doboru kadr w klubie piłki siatkowej na przykładzie drużyny żeńskiej KS Gwardia Wrocław, in: eds., Panfil, R. and Paluszek, K., Zarządzanie i kierowanie w grach zespołowych , WTN, Wrocław, 2003, 69-76.

24. Sikorski, Cz., Motywacja jako wymiana - modele relacji między pracownikami a organizacją, Wydawnictwo Difin, Warszawa, 10-20, 2004.

25. Stoner, J.A.F., Freeman, R.E., and Gilbert, D.R. Jr., Management, Prentice Hall , s. 427, 1995.

26. Stosik A. and Leśniewska, A., Motywacja w nowoczesnym podejściu do zarządzania - wyzwania dla trenerów i coachów, in: Kurzawski, K., ed., Strzelectwo sportowe: nowoczesne rozwiązania szkoleniowe, Z.9, Wydawnictwo Polski Związek Strzelectwa Sportowego w Warszawie and Akademia Wychowania Fizycznego we Wrocławiu, 2012, 59 - 61.

27. Stosik, A., Morawski, M., Zarządzanie kapitałem ludzkim dla menedżerów w sporcie, Wydawnictwo Akademii Wychowania Fizycznego we Wrocławiu, Wrocław, 2009. 
28. Vallerand, R.J. and Standage, M., Motivation in Sport and Exercise Groups: A Self-Determination Theory Perspective, in: Beauchamp, M. R. and Eys, M. A., eds., Group dynamics advances in sport and exercise psychology, Routledge, 2008, 259-278.

29. Witkowski, K., Cieśliński, W. and Stefaniak, T., Kierunki rozwoju przedsiębiorstw sportowych - bariery wzrostu, in: ed. Skalik, J., Zmiana warunkiem sukcesu. Przełamywanie barier rozwoju i wzrostu przedsiębiorstw. Prace Naukowe Uniwersytetu Ekonomicznego we Wrocławiu, nr 219, Uniwersytet Ekonomiczny, Wrocław 2011, 294-300. 